\title{
“No coração, minha terra, no coração do Brasil": Tocantins, discursos identitários, canções
}

"In the heart, my land, in the heart of Brazil": Tocantins, identity discourses, songs

Heitor Martins Oliveira Universidade Federal do Tocantins heitormar@gmail.com 


\section{Resumo}

As canções regionalistas são uma modalidade privilegiada de produção (ou reprodução) simbólica de discursos identitários no Tocantins, estado brasileiro criado em 1989. Revisão de estudos sobre identidade cultural tocantinense, entrevistas com ouvintes qualificados e análise de fonogramas fundamentam uma discussão do processo de trocas e significações relacionadas à inserção deste repertório na dinâmica cultural de negociação simbólica de identidades. As tensões e contradições resultantes podem ser sintetizadas em dois polos: de um lado, o território da política, alinhado à legitimação de autonomia administrativa e de poder; de outro lado, a política do território, em que a ideia de identidade surge como expressão de experiências culturais compartilhadas.

Palavras-chave: canção, regionalismo, identidade cultural, Tocantins

\section{Abstract}

Regional songs are a primary mode of symbolic production (or reproduction) for identity discourses in Tocantins, Brazilian state created in 1989. Review of studies on Tocantins cultural identity, interviews with skilled listeners and analysis of phonograms substantiate a discussion of the exchange process and meanings associated with the inclusion of this repertoire in the cultural dynamics of identity symbolic negotiation. The resulting tensions and contradictions can be summarized in two poles: on the one hand, the political territory, aligned to legitimacy of autonomy and power; on the other hand, the policy of the territory in which the idea of identity emerges as an expression of shared cultural experiences.

Keywords: song, regionalism, cultural identity, Tocantins

\footnotetext{
Heitor Martins Oliveira Possui bacharelado em Música (Regência) e licenciatura em Educação Artística pela Universidade de Brasília (2002 e 2006) e mestrado em Música - Texas State University (2004), título reconhecido no Brasil pela Universidade Federal de Goiás (2008). Atualmente é Professor Assistente da Universidade Federal do Tocantins, vinculado ao colegiado da área de Artes e Filosofia, campus de Palmas e doutorando em Composição Musical pelo Programa de Pós-Graduação em Música da Universidade Federal do Rio Grande do Sul. Tem experiência na área de Artes, com ênfase em Música e Educação Musical, atuando principalmente nos seguintes temas: teoria e análise musical e composição musical.
} 


\section{Introdução}

O Estado do Tocantins foi criado pela Constituição Federal de 1988 e instalado oficialmente como unidade federativa autônoma no dia 1ำ janeiro de 1989. Resultado de reivindicações da sociedade civil e lideranças políticas do então norte goiano, a criação do novo estado resultou em aumento de investimentos públicos na região e significativo crescimento populacional. A capital foi instalada em caráter definitivo na cidade planejada de Palmas, fundada em 1991, que é também a cidade mais populosa do estado, principalmente em decorrência da concentração de migrantes oriundos do interior e de outras regiões do país.

Provavelmente como consequência dessa diversidade de origens geográficas representadas na população e do caráter recente da autonomia político-administrativa, os debates sobre a identidade cultural do Tocantins têm sido constantes. Não são raras afirmativas sobre a necessidade de criar e/ou consolidar tal identidade, embora haja pouca clareza na definição do próprio termo identidade e nenhum consenso sobre o tipo de ação necessária.

Nesse contexto, a criação de canções ditas "regionais" constitui-se como modalidade privilegiada de produção (ou reprodução) simbólica de discursos identitários. Festivais de alcance regional, programas radiofônicos locais e o lançamento, com apoio governamental, de coletâneas de fonogramas de cancionistas e intérpretes radicados no Tocantins são as principais iniciativas que, ao longo dos 26 anos de existência do Estado, vêm proporcionando a divulgação deste repertório e sua inserção no complexo e contraditório território de construção simbólica da identidade regional tocantinense.

No âmbito acadêmico, estudos sobre a temática dos discursos identitários vinculados ao estado do Tocantins têm crescido significativamente nos últimos anos, abarcando uma considerável variedade de perspectivas disciplinares e abordagens metodológicas. Alguns destes trabalhos contêm referências e análises de letras de canções, indicando a relevância desta modalidade de produção cultural para os estudos sobre a temática.

O presente ensaio tem como objetivo discutir a produção de canções no Tocantins e sua relação com os discursos identitários presentes no contexto regional e nacional. Inicialmente, esclareço aspectos conceituais e metodológicos da pesquisa. Em seguida, apresento e discuto resultados, costurando um diálogo entre a produção acadêmica, ouvintes qualificados ${ }^{1}$ e uma amostra do repertório de canções.

\section{Considerações conceituais e metodológicas}

\subsection{Identidade cultural}

Referindo-se inicialmente às culturas nacionais, Hall (2006) as define como "um dispositivo discursivo que representa a diferença como unidade ou identidade" (HALL, 2006, p. 61-62), sendo esse esforço em direção à unidade o sentido principal do termo 
identidade, nesse contexto. Entretanto, as identidades nacionais "não subordinam todas as outras formas de diferença e não estão livres do jogo de poder, de divisões e contradições internas, de lealdades e de diferenças sobrepostas" (ibid., p. 65). Para compreendê-las de maneira plena, é necessário observar as formas adotadas para "costurar as diferenças numa única identidade" (ibid., p. 65). As diferenças regionais foram colocadas sob o teto do estado-nação, que passou a ser "uma fonte poderosa de significados para as identidades culturais modernas" (ibid., p. 49). O processo de globalização, por sua vez, vem afrouxando os laços de identificação com a cultura nacional e reforçando tanto as identidades locais, regionais e comunitárias, quanto identificações globais (ibid., p. 73). Como dispositivo discursivo, "a identidade está profundamente envolvida no processo de representação. [...] Todas as identidades estão localizadas no espaço e no tempo simbólicos" (ibid., p. 71).

A representação ou costura das diferenças como identidade alimenta hibridações, "processos socioculturais nos quais estruturas ou práticas discretas, que existiam de forma separada, se combinam para gerar novas estruturas, objetos, práticas" (CANCLINI, 2006, p. xix). Historicamente, e de forma cíclica, "passamos de formas mais heterogêneas a outras mais homogêneas, e depois a outras relativamente mais heterogêneas, sem que nenhuma seja 'pura' ou plenamente homogênea" (ibid., p. xix-xx). A partir do século $X X$, esses processos de hibridação têm se multiplicado de maneira espetacular.

Ao aproximar minhas observações iniciais sobre identidade cultural no Tocantins a esse substrato teórico dos estudos culturais, dois aspectos parecem especialmente relevantes: primeiro, a preocupação em torno da busca de uma identificação mais local, reação já tida como característica do processo mais amplo de globalização; segundo, a percepção de uma "crise" identitária, coerente com a conceituação teórica de identidade como uma construção espaço-temporal, permeada de contradições, conflitos e processos dinâmicos de hibridação. E a partir dessas considerações, formula-se uma primeira questão: no contexto específico do Tocantins, quais são os processos, conflitos e contradições da construção espaço-temporal de sua identidade? Nesse trabalho, essa questão foi abordada prioritariamente a partir de uma pesquisa bibliográfica.

\subsection{Canção, pontos de escuta, autenticidade, regionalismo}

O reconhecimento da integridade discursiva da canção exige ir além da compreensão mais corriqueira do gênero como mera sobreposição de letra e música: "A existência de canções é viabilizada pelos múltiplos modos com os quais esse instrumento notável e flexível, a voz humana, explora um complexo conjunto de recursos auditivos" (FINNEGAN, 2008, p. 29). Alguns desses recursos podem ser sinalizados nos textos (letras), outros auxiliados por modernas tecnologias de áudio e todos sublinhados pelos inúmeros modos de emissão da voz humana como solista ou em conjuntos, com ou sem acompanhamentos em todas suas nuances possíveis (ibid., p. 30). A performance vocal, mesmo quando registrada em fonograma, negocia expectativas, convenções e inovações em um processo dinâmico de aglutinação de sentidos. 
No Brasil, a riqueza deste processo dinâmico e o papel preponderante da canção como produção cultural refletem-se na produção acadêmica. Assim, "tão férteis quanto a própria criação musical, os múltiplos discursos sobre a música popular confirmam sua condição de tema privilegiado da cultura brasileira" (TRAVASSOS, 2005, p. 94). Verifica-se a existência de diversos "pontos de escuta", abordagens diferenciadas da mesma temática.

O meu ponto de escuta da produção recente de canções no estado do Tocantins tem como foco o processo discursivo de produção e recepção, de trocas e significações relacionadas à sua inserção na dinâmica cultural de negociação simbólica de identidade. Esse ponto de escuta, aqui delimitado em torno de uma amostra do repertório regional tocantinense, é tema recorrente em discussões informais e acadêmicas sobre a música brasileira popular em geral. Como destaca Ulhôa (1997, p. 89), a identidade da música brasileira é um território em disputa. A disputa é tanto interna, entre os campos erudito/folclórico/popular, quanto na oposição entre música brasileira e música estrangeira. Para a autora, além de elementos sonoros objetivos, fatores intersubjetivos como as origens sociais e o público de cada gênero são determinantes para construção de significados e atribuição de valores estéticos. "De fato, o que é música brasileira popular e o que é uma identidade nacional brasileira é uma construção" viabilizada pelas relações de oposição (ULHÔA, 1997, p. 95).

Zan (2001) analisa o desenvolvimento do mercado fonográfico nacional a partir da apropriação de elementos da cultura popular para produção musical massiva. A sucessão de tendências no final do século $X X$, como sertanejo, pagode, axé music, manguebeat e rap articulam elementos locais e globais. Buscam legitimação no discurso de autenticidade da cultura popular, ainda que de maneira fragmentada pelos recortes regionais e de classe (ZAN, 2001, p. 118-119).(exemplo de citação apenas)

A autenticidade, entretanto, também não se sustenta em critérios factuais ou sonoros inequívocos, mas habita um espaço discursivo característico.

Entendemos a categoria da autenticidade, não como um traço inerente ao objeto ou ao evento "original", mas uma reconstituição social, uma convenção que deforma parcialmente o passado, mas que nem por isso deve ser pensada sob o signo da falsidade (NAPOLITANO \& WASSERMAN, 2000, p. 168).

Ou seja, embora não possa ser defendida como fato histórico, a origem dos gêneros musicais existe como representação social determinante para seus processos de produção e recepção. Essa representação permeia a invenção de tradições, que se legitimam a partir da "noção de uma herança que atravessa o tempo presente e se projeta para o futuro, causando uma prazerosa sensação de permanência e de comunidade simbólica" (TROTTA \& LOPES, 2009, p. 9). A invenção da tradição não significa a fabricação completa de práticas e produtos musicais relevantes. Representa, sim, a instituição de práticas ritualizadas que constroem, por meio da força narrativa do mito, um elo afetivo e mercadológico entre passado e presente. "Assim, a ideia de tradição deve ser entendida como um discurso, como uma forma de construir uma identidade, um nós em oposição a uma outra identidade" (TROTTA \& CASTRO, 2001, p. 69). 
O discurso da tradição assume caráter de gesto criativo intencional no repertório de canções regionalistas discutido por Alencar (2004). Em sua pesquisa, a autora aborda a música regionalista do centro-sul brasileiro, produzida por hábeis cancionistas no contexto urbano, mas com inspiração no mundo rural, a qual "é reveladora de trocas multivocais - particularmente entre autores e seu público, entre litoral e sertão, entre erudito e popular, na medida que são produzidas na tensão entre o local e o externo" (ALENCAR, 2004, p. 4). As trocas e tensões enumeradas são justamente as características que dão relevância às canções regionalistas como discurso identitário na pós-modernidade.

A historiadora aponta a dialética das imagens literárias e musicais ligadas a antigas tradições brasileiras, mas destinadas a um público contemporâneo, apresentadas pelos cancionistas e intérpretes regionalistas. Estas imagens "são sincrônicas com uma determinada época, pretérito e presente se juntam como numa constelação, num momento fulgurante" (ibid., p. 10). E conclui:

podemos afirmar que música regionalista, entre outras manifestações vigorosas da cultura e da identidade no sertão - entendido como uma fronteira - não desapareceu diante da modernidade e do progresso. Ao contrário, abre seu caminho, instituindo o novo onde parecia haver ameaça de desaparecimento (ALENCAR, 2004, p. 10).

A canção regionalista, portanto, pode ser compreendida como gesto criativo intencional, constituído a partir de imagens literárias e musicais reveladoras de trocas entre passado e presente, tradição e modernidade, constituindo-se como discurso simbólico da identidade cultural. No contexto específico da produção e recepção de canções no Tocantins, como se manifesta esse gesto criativo intencional e como pode ser caracterizado o regionalismo? As tentativas aqui apresentadas de resposta a esse questionamento, central para os objetivos do trabalho, foram construídas relacionando pesquisa bibliográfica, entrevistas com ouvintes qualificados e análise de fonogramas.

\subsection{Considerações sobre a análise de fonogramas}

No que se refere ao estudo analítico da canção popular brasileira, é relevante remeter à contribuição de Luiz Tatit. O pesquisador desenvolveu uma abordagem semiótica que busca descrever a compatibilidade de letra e melodia como núcleo de autoria do cancionista e expressividade da canção popular brasileira (TATIT, 2004, p. 141). Suas análises enfatizam as relações da letra com o contorno melódico segmentado em módulos delimitados por sustentações.

O trabalho de Coelho (2007) dá continuidade à linha de pesquisa iniciada por Tatit. O ponto fundamental de sua contribuição é o reconhecimento da empreitada como análise de fonogramas (melodia-letra/arranjo) e não simplesmente de canções (melodia-letra). A análise do fonograma se impõe ao pesquisador "posto que, em geral, este é o suporte preferencial de registro da manifestação cancional" (COELHO, 2007, p. 189). 
Coelho (2007) discute o papel do arranjo para constituição dos modos de existência da canção popular nas relações de sentido antagônicas, nas convenções de uso de instrumentos e na apropriação de discursos.

A preocupação de analisar a produção e recepção de canções de forma abrangente também permeia o pensamento de Finnegan (2008, p. 18), que aborda a canção como performance e o fonograma, registro de uma performance idealizada, como documento histórico aglutinador das expressões identitárias de seus agentes criativos. Nessa perspectiva, a canção revela-se como rica construção de significações, derivadas da interação e elaboração imaginativa de atributos musicais (não apenas melódicos), verbais (não apenas semânticos e poéticos) e performativos. E é dessa perspectiva que incluo na discussão análises interpretativas e pessoais de alguns fonogramas, buscando gestos criativos regionalistas de canções específicas e sua relação com os processos, conflitos e contradições mais gerais da construção identitária no Tocantins.

\section{Tocantins, identidade, canções}

Na canção Meu Tocantins , Lucimar retoma a temática literária celebrizada no Brasil pela Canção de Exílio de Gonçalves Dias (1823-1864). O paralelo com o poema romântico se evidencia não apenas pela citação dos dois primeiros versos "Minha terra tem palmeiras / Onde canta o sabiá" de Dias, mas também pelo saudosismo e ufanismo que dominam o fonograma (Figura 1).

A canção é pontuada por hábeis, exaustivas referências a riquezas naturais e traços culturais da vida rural. As sonoridades de cordas dedilhadas, acordeão e percussões compõem o acompanhamento para os vocais igualmente "sertanejos": a linha melódica principal, expressivamente interpretada pelo próprio cancionista, é reforçada por uma segunda voz ao longo da estrofe. No refrão, um discreto coro confere preenchimento harmônico aos versos "Ei, Tocantins, não faz assim que eu posso não aguentar / Ei, Tocantins, tem dó de mim, saudade quer me matar" (Figura 2). 

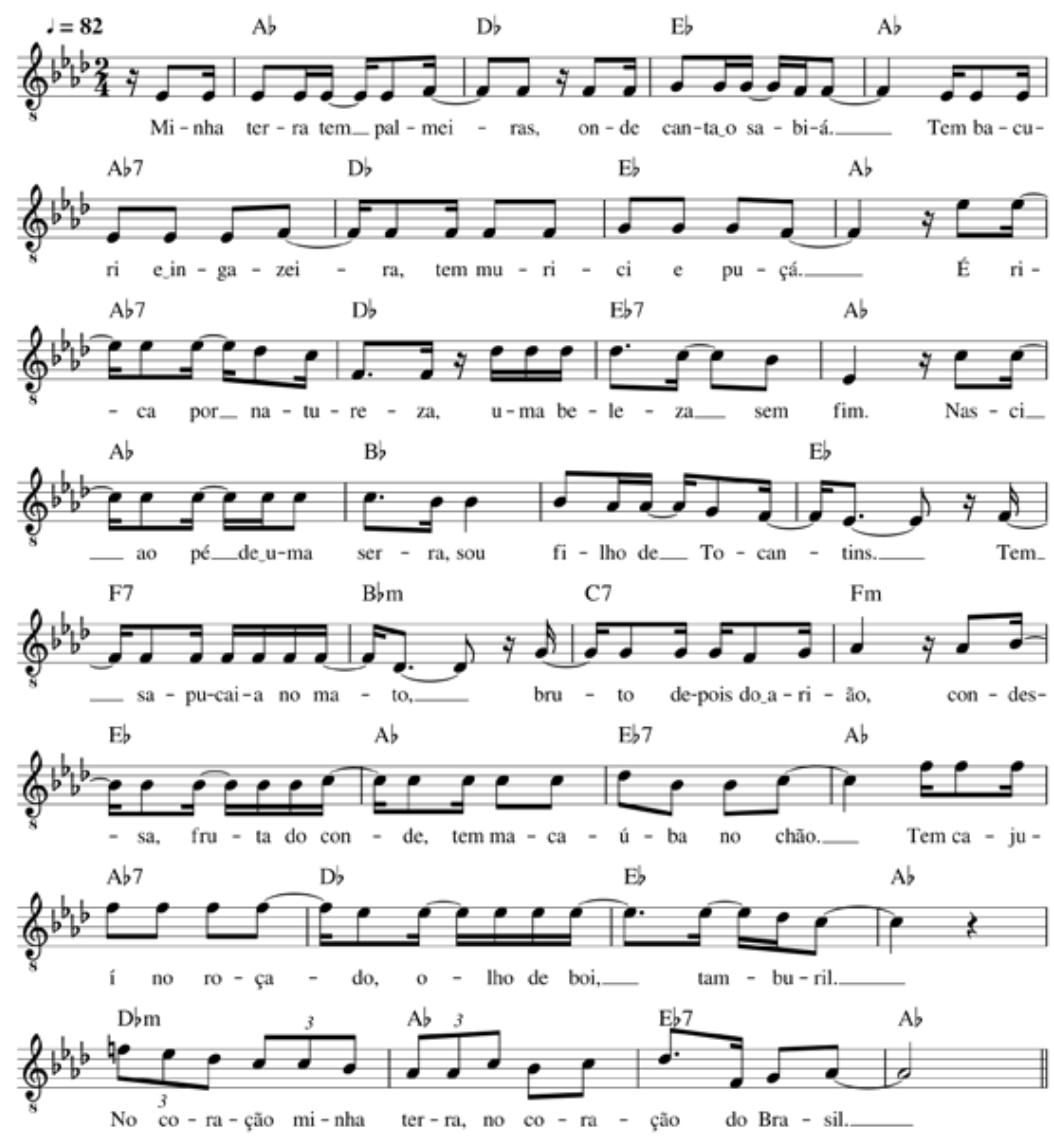

Figura 1: primeira estrofe de Meu Tocantins (Lucimar)

No todo, desenha-se um cenário bucólico. A narrativa do sujeito da canção, retratado como um "filho de Tocantins" saudoso de sua terra natal, reverbera no coletivo, representado pelo coro. A canção remete o ouvinte a uma experiência sentimental coletiva com um Tocantins essencialmente puro e intocado, discurso identitário fundamentado na estratégia de vinculação afetiva: "No coração, minha terra, no coração do Brasil".

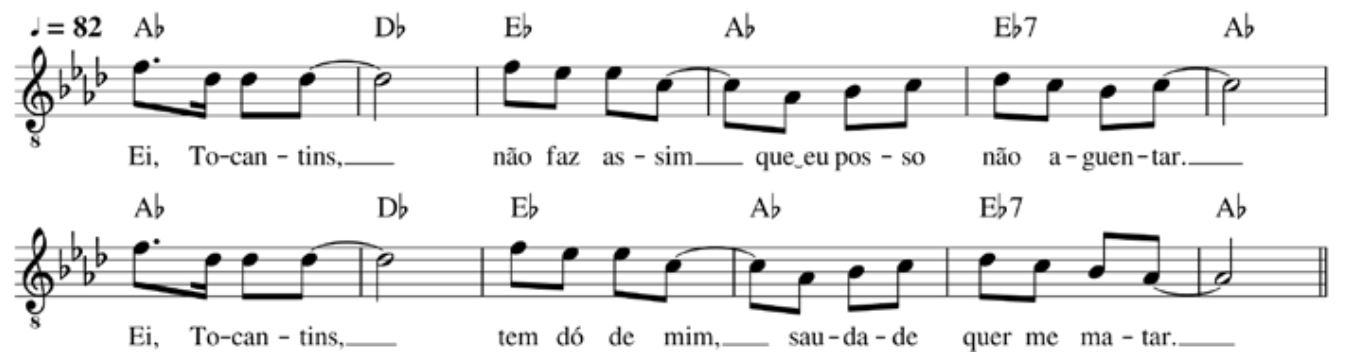

Figura 2: refrão de Meu Tocantins (Lucimar)

A letra é marcada pela insistente repetição do "Tocantins" como ideia central da identidade que se pretende construir, reforçar. A musicalidade, por outro lado, pode ser identificada como "goiana" ou, de maneira mais geral, "sertaneja" (ALENCAR, 2000). A letra, tomada isoladamente, sugeriria a imagem de uma identidade exclusiva e unifi- 
cada. A escuta musical, entretanto, revela a complexidade das relações e construções simbólicas da cultura regional.

As estratégias composicionais de Meu Tocantins foram reconhecidas pelos ouvintes qualificados como características das canções "regionais". No vasto repertório de canções agrupadas sob este rótulo, diversas outras estratégias podem ser observadas, remetendo aos diferentes discursos e experiências compartilhadas que habitam o espaço simbólico da identidade cultural no Tocantins.

\subsection{Processo histórico, canções, identidades}

Uma das principais vertentes de discurso acadêmico sobre a questão da identidade cultural no Tocantins fundamenta-se na descrição e análise do processo histórico de povoamento e desenvolvimento socioeconômico da região que, a partir da Constituição Federal de 1988, passou a constituir a mais recente unidade federativa. Podendo ser relacionado à apropriação mais geral da categoria "sertão" como princípio explicativo e identitário brasileiro (ALENCAR, 2000, p. 3), o discurso historiográfico enfatiza o processo social e político que culminou com a autonomia do estado. Esse processo remonta ao período colonial e está estreitamente associado ao povoamento e construção de modos de vida e interação entre os diferentes grupos sociais na região (CAVALCANTE, 2001, p. 6).

O Tocantins foi, desde o século XVII, caminho frequente de bandeiras paulistas em busca de ouro e apresamento de índios a serem cativados, e posteriormente, no século XVIII, tornou-se também fronteira de expansão das fazendas de gado que logo se espalharam por todo o Centro-Oeste, Norte e Nordeste: da Bahia ao Maranhão. No entanto, o povoamento mais efetivo do entorno do rio Tocantins se daria com a mineração (FLORES, 2009, p. 51).

O povoamento mais efetivo ocorreu, portanto, a partir do final do século XVIII, quando foram descobertas as principais minas auríferas da região norte da Capitania de Goiás (ibid., p. 51). Flores (2009, p. 55) destaca ainda a revogação da proibição de navegação dos rios Tocantins e Araguaia, em 1782, como marco de estímulo ao povoamento nas margens dos dois rios. A proibição havia sido imposta pela Coroa portuguesa como medida para tentar refrear o contrabando de ouro explorado na região que, por ser erma, era difícil de ser fiscalizada (ibid., p. 60).

Esse marco, entretanto, não significou a resolução imediata dos problemas. A historiadora registra, por meio da análise de diversos documentos datados do século XIX ao início do século $X X$, o descontentamento da população ribeirinha com a falta de investimentos governamentais na navegabilidade do rio Tocantins (ibid., p. 61-75). As sucessivas reivindicações dos habitantes da região quanto aos problemas de seu isolamento e descaso por parte dos governos são tão marcantes que podem ser consideradas um traço significativo da identidade territorial.

Apesar da dificuldade de navegação e do risco constante de conflitos com povos indígenas, o rio Tocantins desempenhou o papel de canal de comunicação e transporte 
de bens para a região. Com as sucessivas ondas de modernização ao longo do século XX e início do século XXI, as transformações se aceleraram, principalmente pelo aumento populacional, aumento da produção agrícola e urbanização (OLIVEIRA, 2008, p. 164). Esse processo resultou em "traços identitários bem particulares, marcados por características regionais e culturais", evidenciados pelas atividades socioeconômicas desempenhadas e pelos contatos entre diferentes grupos étnicos e com novos imigrantes (ibid., p. 166-167).

A relevância da história prévia à autonomia político-administrativa ecoa nas considerações dos ouvintes qualificados sobre a produção musical local:

O Tocantins, por ser tão novo constitucionalmente, não significa que não tenha uma tradição musical muito mais enraizada, há mais de 200 anos, do ponto de vista das músicas, manifestações folclóricas, as festividades, as brincadeiras, as rodas, as suças, as catiras, essas coisas que aqui criaram um sotaque diferente dos lugares que a gente conhece (E3).

Nesta e em outras falas dos entrevistados, a produção de imagens evocativas das manifestações musicais tradicionais e do "sotaque diferente" dos vales dos rios Tocantins e Araguaia é indicada como importante característica do discurso identitário das canções regionalistas tocantinenses.

Historicamente a construção do "sotaque" regional pode ser associada ao fato de que os habitantes da área geográfica do atual Estado de Tocantins buscaram sua integração e desenvolvimento por meio da ativação e dinamização de rotas de navegação comercial que, por fatores naturais, conduziam ao Pará, visto que os rios Tocantins e Araguaia deságuam no Amazonas. As tensões geradas por esta configuração geográfica, em oposição à vinculação político-administrativa com a província de Goiás, estão na raiz das reivindicações que culminaram no processo de autonomia. A ligação com o Pará e com a região amazônica é um dos fatores no fortalecimento de identidade a partir do contraste: Tocantins não é Goiás.

Conforme relataram os entrevistados, cancionistas e intérpretes da geração de Juraíldes da Cruz, Genésio Tocantins e Braguinha Barroso, naturais do norte goiano, que emigraram para Goiânia a partir da década de 1970, buscavam a afirmação deste contraste identitário no âmbito musical. Oriundos de uma experiência fortemente rural, mas distinta das duplas "caipiras" mais presentes ao sul de Goiás, se depararam na capital goiana com um contexto urbano, onde os campos da música erudita e da MPB (em diálogo mais próximo com as correntes vigentes à época na indústria fonográfica), já se firmavam por meio de instituições e eventos (SANTOS JÚNIOR, 2010).

A canção Dodói , de Juraíldes da Cruz, destaca-se pela musicalidade que se aproxima muito mais das sonoridades da música do norte do país. Assim, estabelece vínculos com heranças e discursos relevantes para a identidade regional. Na gravação de Braguinha Barroso, o caráter rítmico com tempero "amazônico" é bem estabelecido desde a introdução (Figura 3). 


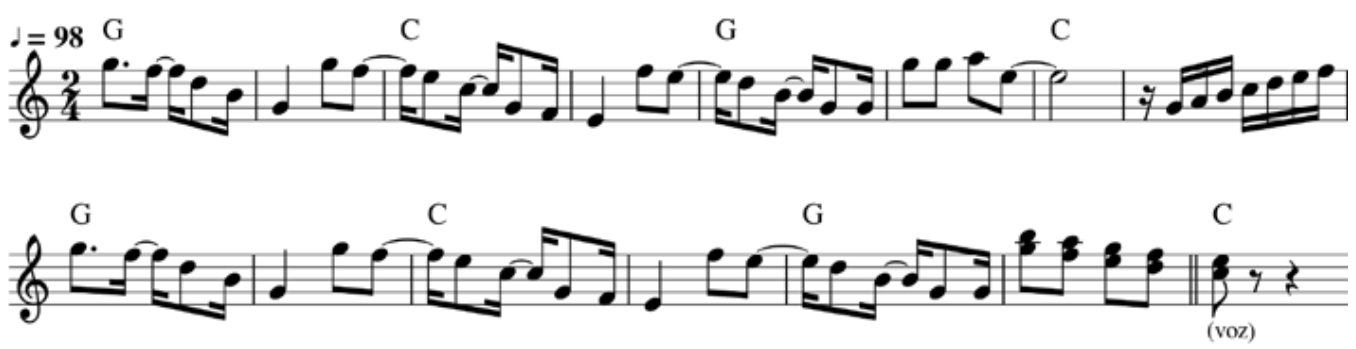

Figura 3: introdução de Dodói (Juraíldes da Cruz), na gravação de Braguinha Barroso

A musicalidade da canção é calcada na malemolência dançante do acompanhamento e em variantes linguísticas com implicação rítmica: elisões ("d'eu"), supressões ("ocê", "juntim") e acréscimos fonêmicos ("Nóis"). As variantes linguísticas e a pronúncia do intérprete constituem um sotaque peculiar, que mistura o acento nortista com o "jeitim" goiano de falar. Algumas expressões, como a referência ao "pé de juá" e a lembrança de que "Nóis banhava no riacho" reconstroem imagens da vida rural. Em Dodói, a performance da palavra cantada reflete a dinâmica cultural híbrida no território do atual estado do Tocantins.

Outro tema que se destaca na leitura das pesquisas historiográficas é o contato e assimilação de grupos sociais diversos (ribeirinhos, indígenas, viajantes e migrantes). A presença indígena foi um fator determinante para as dinâmicas culturais na região do atual Estado do Tocantins. Nos relatos iniciais, as relações são conflituosas. Os povos indígenas aparecem ou como ameaça à segurança da navegação nos rios Tocantins e Araguaia, ou como alvo das investidas de bandeirantes em expedições de capturas de escravos. Em função destes conflitos, os povos indígenas se viram gradativamente isolados. No século XX, de maneira geral, deixaram de ser vistos como ameaça. Entretanto, sua integração à sociedade tocantinense contemporânea, sem prejuízo de sua identidade cultural, é uma questão complexa em constante debate.

Do repertório explorado ao longo da pesquisa, destaco uma canção que se vale de referências indígenas como estratégia de construção simbólica de identidade, Não vivo mais em mim, de Paulo Albuquerque, cancionista gaúcho radicado no Tocantins. $O$ sujeito da canção é um guerreiro javaé da llha do Bananal que reivindica todas as perdas sofridas pelos povos indígenas diante da usurpação de sua terra e de sua cultura: "Não sou dono nem de minhas trilhas / Meus costumes já não têm valor".

Com melodia e acompanhamento organizados em métrica ternária (Figura 4), o arranjo da canção comporta a mesclagem da musicalidade gaúcha do autor com imagens literárias e sonoras indígenas, combinação que evidencia aspectos da dinâmica cultural de um estado formado e povoado de maneira híbrida. Por um lado, a inserção de autênticas expressões vocais indígenas no início da faixa proporciona uma ambientação sonora sugestiva. Por outro lado, as intervenções com timbres sampleados de flautas andinas, além de uma perceptível artificialidade, carregam referências estereotipadas e desgastadas. De maneira geral, entretanto, a estratégia regionalista de dialogar e identificar-se com a triste realidade de um povo indígena se sustenta artisticamente no fonograma. Até por se tratar de uma das poucas canções que, em tom de lamento, 
questiona a utopia do novo estado, ao denunciar o drama de seus habitantes mais antigos.

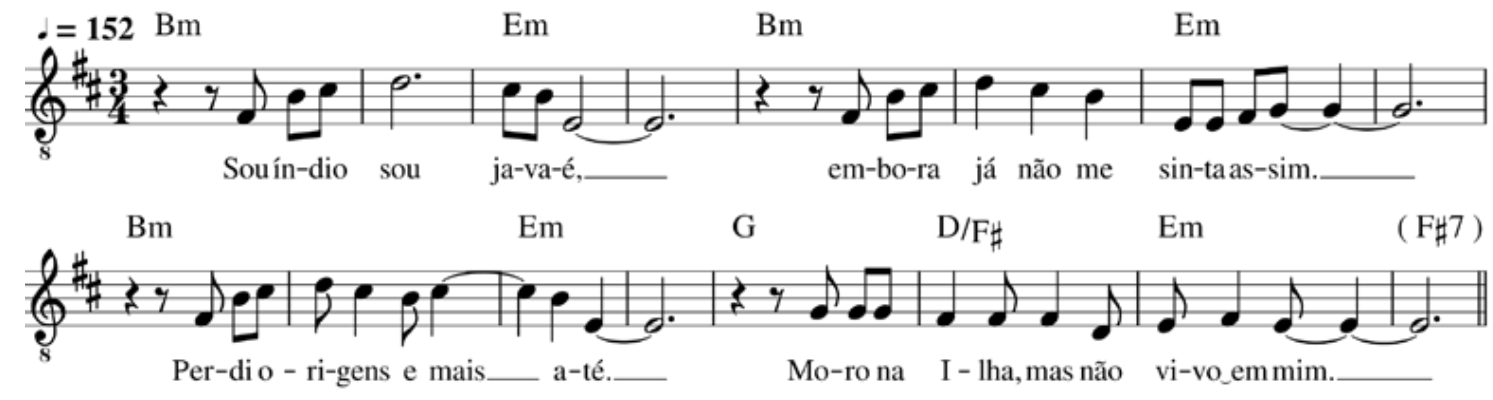

Figura 4: trecho de Não vivo mais em mim (Paulo Albuquerque)

\subsection{Legitimações, ironias, memórias, canções, identidades}

Outro relevante polo do discurso acadêmico sobre a identidade cultural no Tocantins aborda a história recente, a partir da autonomia político-administrativa do estado, com viés crítico sobre o cenário político. $O$ foco destes trabalhos são discursos e simbologias associados à intencionalidade de produzir identificações e influenciar o imaginário coletivo para legitimação do poder político.

Partindo do conceito de espaço de representação, Rodrigues (2009) analisa a criação e implantação do estado do Tocantins, com ênfase na questão da legitimação do poder político. $\mathrm{O}$ autor aponta relações entre política e religiosidade, evidenciadas na proposição de verdadeiros mitos em discursos e simbologias como o Hino do Tocantins (RODRIGUES, 2009, p. 66) e os murais que fazem parte da decoração do Palácio Araguaia (ibid., p. 71), sede do governo local. Por meio dessas simbologias, "as diferentes leituras foram sendo construídas e as representações criadas, alimentando um imaginário coletivo no qual se misturaram mitos e verdades, cada qual contado de uma forma diferente" (ibid., p. 70).

O pesquisador retoma o tema, entrevistando 32 moradores do norte e extremo norte do estado. O foco específico, neste caso, é "a tríade espaço de representação-identidade-lugar e suas implicações sobre o ser/estar no norte e extremo norte do Estado do Tocantins" (RODRIGUES, 2011, p. 25).

No caso da criação do Estado do Tocantins, as identidades e experiências ganharam novo contorno a partir de sua emancipação. Até 1988, a região que hoje constitui o território tocantinense pertencia ao norte do Estado de Goiás. As referências identitárias, portanto, eram goianas e as pessoas se reconheciam enquanto tal. Da noite para o dia, de 31 de dezembro de 1988 para o dia 01 de janeiro de 1989, todos amanheceram tocantinenses. Isso provocou a construção de novos sentidos sobre as representações que os sujeitos possuíam sobre, ago$\mathrm{ra}$, ser tocantinense. As identidades territoriais foram, aos poucos, inventadas para produzir uma noção de pertencimento ao estado tocantinense (ibid., p. 26).

E acrescenta: "estas invenções culturais são típicas de regiões nas quais as refe- 
rências identitárias não estão ainda muito claras, mas é necessário serem criadas para legitimar ações políticas" (ibid., p. 26). A ênfase no contraste, associando norte goiano a abandono e Tocantins a progresso e bem-estar, tornou-se o motor da noção de pertencimento à nova identidade. Entretanto, nas falas de seus entrevistados, o autor destaca as heranças da territorialidade cultural do norte goiano. Dessa forma, adverte que

a identidade cultural regional torna-se algo que extrapola as construções políticas e torna-se uma questão de pertencimento territorial. Deixa de ser um território da política para ser uma política de território. Território e cultura, portanto, são elementos indispensáveis na análise das identidades regionais, coletivas ou individuais (ibid., p. 27).

A crítica de Rodrigues sobre a interferência do discurso político no discurso identitário situa a breve discussão sobre a canção Meu Tocantins, apresentada no início da sessão 2 deste texto. Na análise, eu sugeria uma tensão entre a identidade enunciada, principalmente pela repetição e ênfase em "Tocantins", palavra carregada de conotações políticas, e a identidade simbolicamente construída nas sonoridades da canção, cheias de referências territoriais e regionais que não se limitam ao aspecto político-administrativo.

É importante destacar que essa tensão não é exclusividade de Meu Tocantins. Enfatizar e repetir "Tocantins" e referências diretas a suas riquezas naturais e culturais, denominações de localidades, expressões relativas a costumes, objetos e atividades socioeconômicas típicas da região, são expedientes recorrentes em boa parte do repertório de canções regionais. Os entrevistados também reconhecem essa característica e afirmam que coletâneas desenvolvidas com apoio governamental costumam adotar como critério "referências locais, nominais, sítios locais, paisagens, nomes que tinham essa proposta, vamos dizer assim, de uma sonoridade de Tocantins" (E3). No entanto, favorecem textos que não apenas citam referências naturais ou culturais, mas exploram suas potencialidades musicais, compondo uma espécie de paisagem sonora do sotaque e ritmos orais da região.

Araújo (2011), partindo de uma abordagem sociolinguística, desenvolve uma análise da canção Nóis é jeca mais é jóia (autoria de Juraíldes da Cruz e interpretação de Genésio Tocantins) que evidencia a riqueza sonora e de construção de sentidos na linguagem regional. A proposta da autora é "retratar as variações linguísticas expressas nesse texto, buscando identificar as marcas dos sujeitos presentes no texto" (ARAÚJO, 2011, p. 10).

Assim, o sujeito coletivo da canção é definido pela autora como o homem rural, sertanejo, rústico, mas ao mesmo tempo adaptado à vida moderna (ibid., p. 12). As variações linguísticas remetem a dados geográficos, costumes e modos de vida; autoimagem de simplicidade, sabedoria prática e honestidade. Constroem ainda "tiradas" cômicas, dialogando com informações disponíveis nos meios de comunicação de massa (ibid. p. 12-15). 

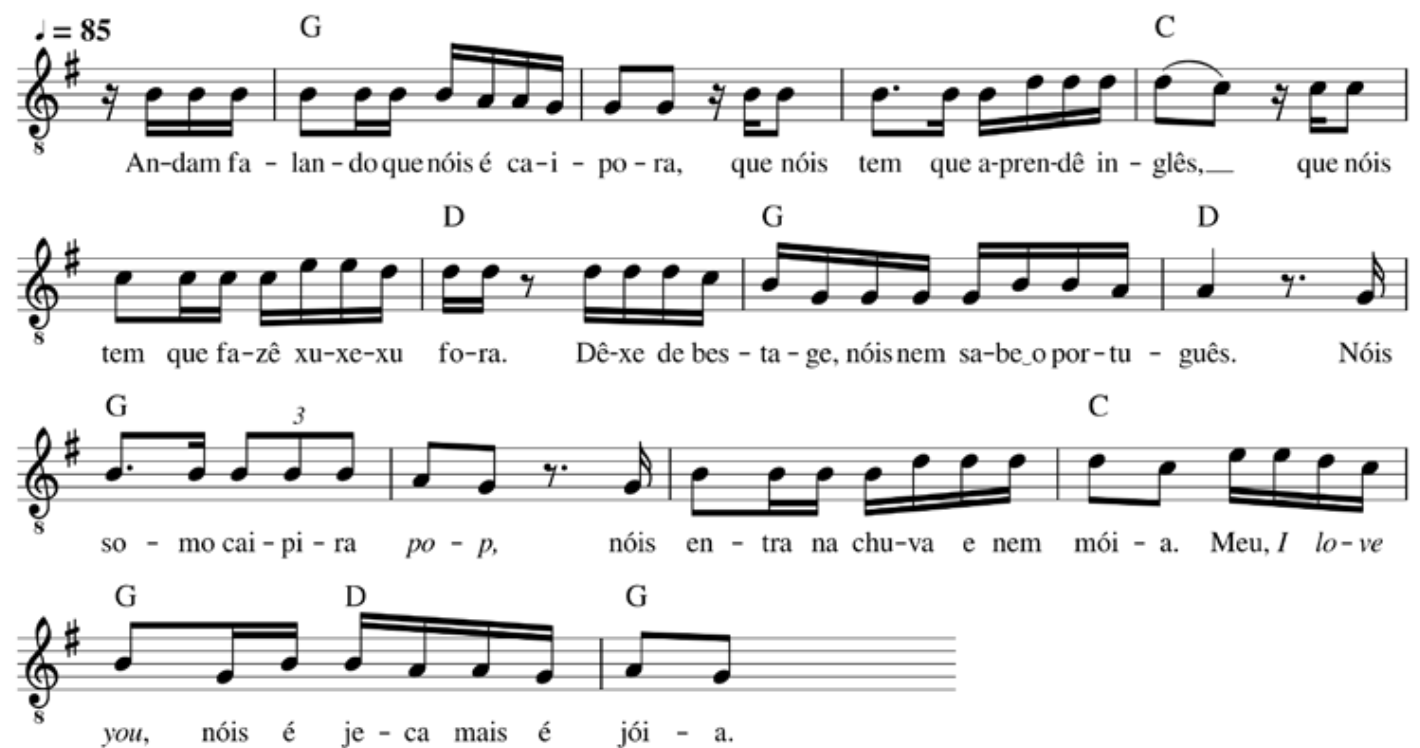

Figura 5: trecho de Nóis é jeca mais é jóia (Juraildes da Cruz), na interpretação de Genésio Tocantins: "Andam falando que nóis é caipora..."

No trecho transcrito na Figura 5, os vocábulos "xuxexu" e "pop" evidenciam o recurso da intertextualidade, inclusive no caso em que o cancionista aborda de maneira cômica a substituição de fonemas, remetendo ao nome da apresentadora Xuxa. Dessa forma, o sujeito da canção contrasta sua realidade com as condições de exaltação e fama que personalidades como a Xuxa e cantores pop conquistaram em todo o país, chamando atenção para o fato de que o sucesso na indústria fonográfica está ligado ao contexto de produção da música (ibid., p. 15).

Quanto aos aspectos fonológicos, a pesquisadora enumera ocorrências de supressão, acréscimo e substituição fonêmica. Conclui que há um papel duplo dessas variações fonológicas na canção: enfatizar a linguagem caipira e sertaneja, ao mesmo tempo em que proporciona construções melódicas e rítmicas peculiares (ibid., p. 16). Além disso, a oposição constante da linguagem caipira com expressões características de outras regiões (como o vocativo "meu") e de idiomas estrangeiros ("I love you") cumpre função irônica na canção. A mesma estratégia se evidencia no refrão (Figura 6).
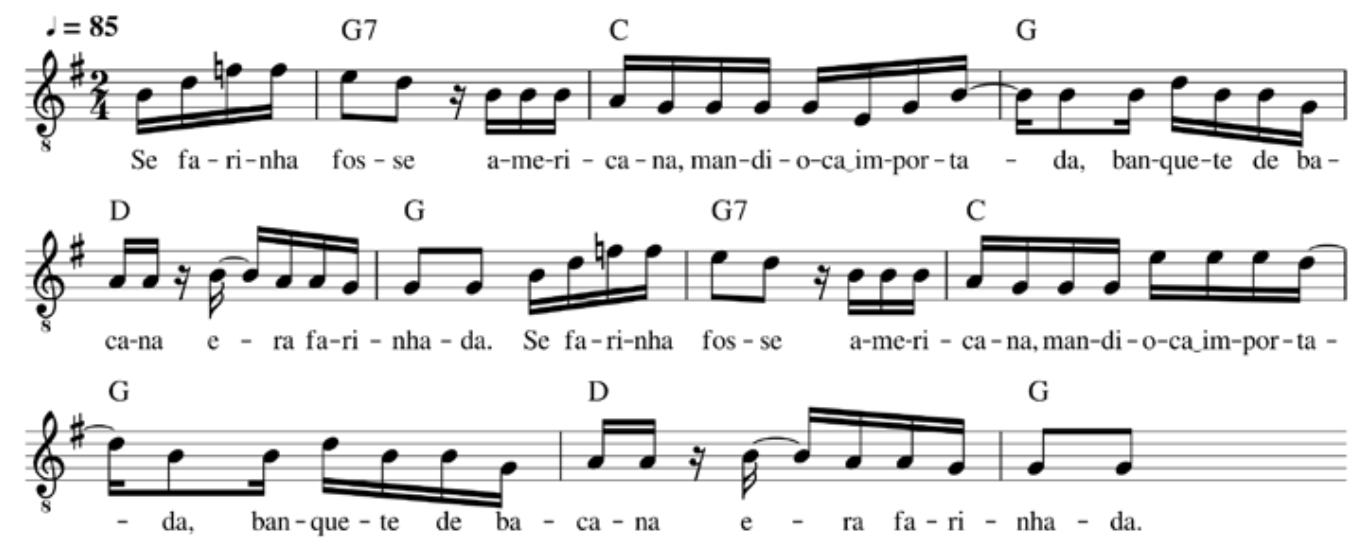

Figura 6: trecho de Nóis é jeca mais é jóia (Juraildes da Cruz), na interpretação de Genésio Tocantins: "Se farinha fosse americana..." 
Os versos representam uma reação irônica à dominação cultural. Tanto na gravação de Genésio Tocantins, quanto na gravação anterior, realizada no Festival Canta Cerrado de 1995, o trecho é entoado em tom brincalhão, com acompanhamentos que mesclam sonoridades de xote e blues. A aparente e bem humorada autodepreciação, é justamente o veículo da ironia, denunciando o preconceito nas relações entre sujeitos de diferentes regiões geográficas e classes sociais.

Ironia semelhante pontua a canção Pequi blues ballad, de Reneu do Amaral Berni, gravada por Chiquinho Chocolate. O blues, gênero musical originário do sul dos Estados Unidos da América, caracteriza-se por um estrito vocabulário de padrões harmônicos, rítmicos e melódicos. Expressividade e criação de variações são os elementos explorados pelos cancionistas e intérpretes do gênero. Nesta canção, o uso intencional - e competente - de referência ao padrão composicional estrangeiro é o ponto de partida para a construção de um discurso identitário calcado nas tensões entre local e externo. Cancionista e intérprete trabalham com essas tensões de forma cômica.

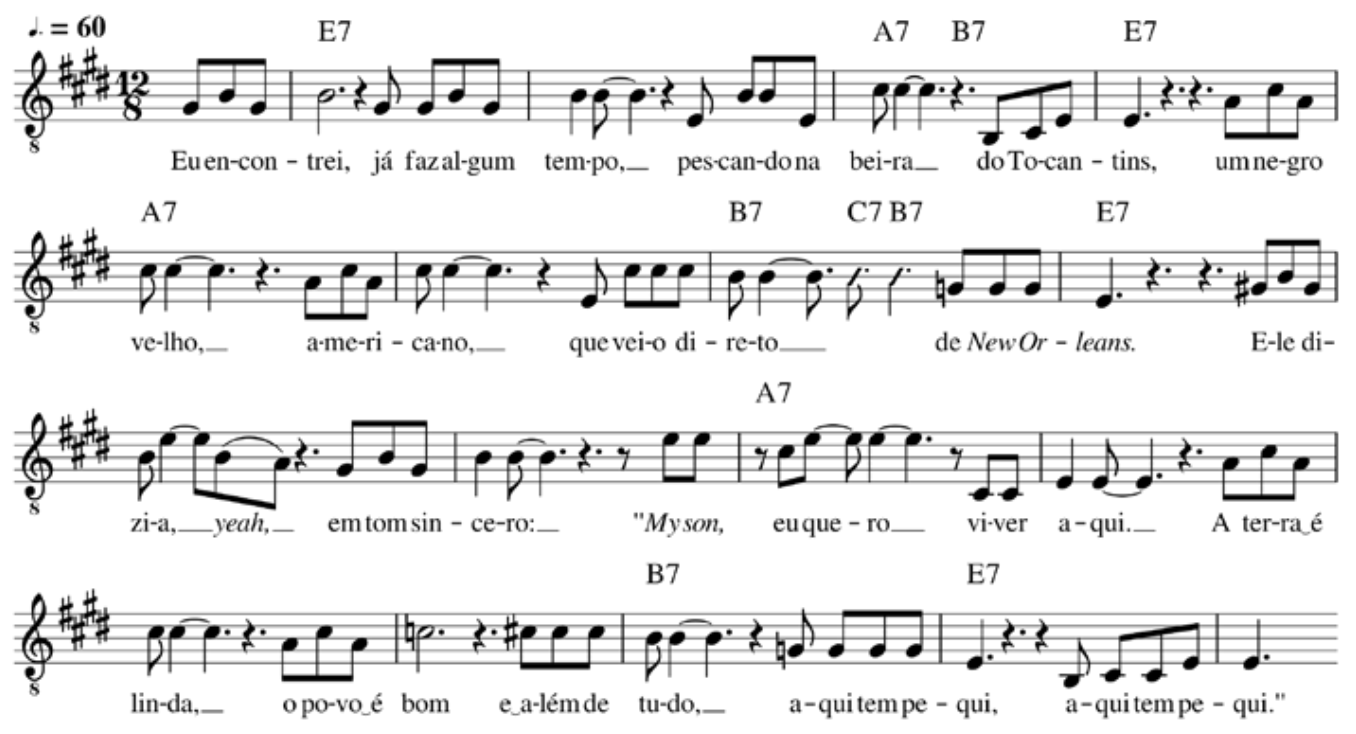

Figura 7: trecho de Pequi blues ballad (Reneu do Amaral Berni), na interpretação de Chico Chocolate

A canção narra o encontro entre um nativo da beira do rio Tocantins e um negro americano que imigrou para desfrutar das belezas da terra, da convivência do povo ribeirinho e, principalmente, da iguaria do cerrado: o pequi (Figura 7). Na segunda estrofe, descobrimos que o nativo tocantinense aprendeu a tocar blues com o americano. A canção remete, por meio deste encontro mítico, ao processo de trocas que caracteriza a dinâmica cultural.

No refrão (Figura 8), Chico Chocolate habilmente se vale de recursos vocais característicos do gênero. $O$ ápice sentimental da interpretação, que coincide com o ápice melódico, atingido nos versos "Às vezes, até apanho do pé / E como cru e como cru", gera o impacto final do jogo cômico construído na canção. A apreensão dessa comicidade depende da intimidade do ouvinte com hábitos alimentares locais e de um sen- 
timento compartilhado de autoafirmação diante das produções culturais externas. $O$ gesto criativo regionalista, neste caso, abdica das sonoridades tradicionais e busca referências no cenário de identificações globais da atualidade. Admite-se o externo, mas não sem o acréscimo de intervenções regionais.

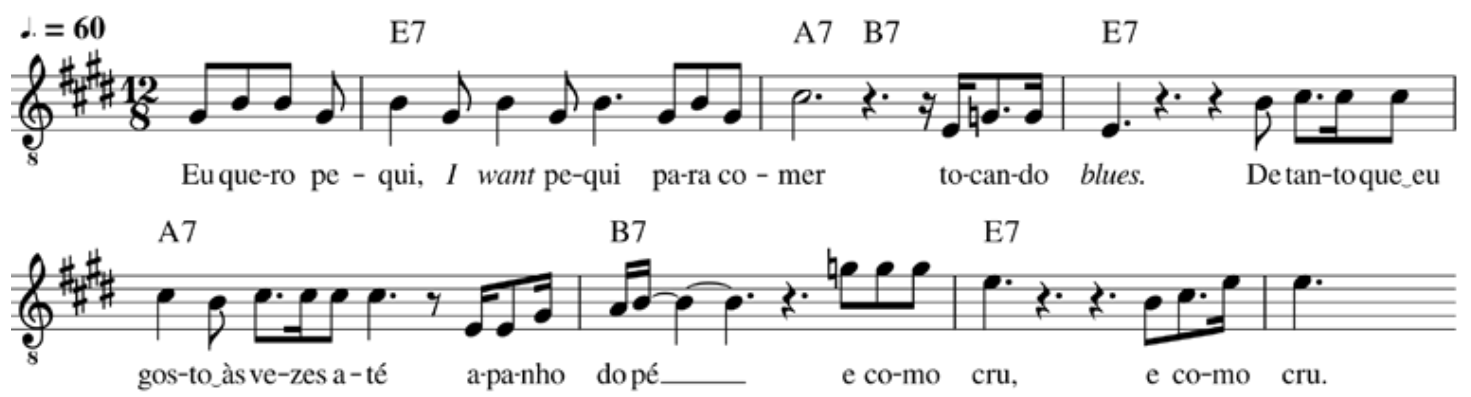

Figura 8: refrão de Pequi blues ballad (Reneu do Amaral Berni), na interpretação de Chico Chocolate

A tensão entre o local e o externo alimenta a dinâmica de discursos de fortalecimento das identidades, a exemplo do próprio samba que ao longo das décadas de 1930 e 1940 afirmou-se a partir da imagem de uma música nacional em constante ameaça pela música estrangeira. Reforçado pela contribuição de intelectuais e literatos formadores de opinião, esse discurso estava presente nas próprias imagens literárias e musicais evocadas por obras como Canção para inglês ver, de Lamartine Babo, Goodbye, de Assis Valente, Yes, nós temos banana, de João de Barro e Disseram que eu voltei americanizada, criada por Vicente Paiva e Luiz Peixoto para interpretação de Carmem Miranda (BONILLA, 2011).

O rio Tocantins, cenário da narrativa de Pequi blues ballad, também figura de maneira proeminente em diversas outras canções do repertório regional. Uma amostra significativa, o CD Cantocantins 2, com canções premiadas no 20 Festival da Canção do Tocantins, é mencionada em um ensaio recente sobre memória e patrimônio cultural (MESSIAS, 2008). A autora destaca que, "das doze músicas ali gravadas, sete fazem referência ao rio Tocantins" (ibid., p. 1). Os cancionistas citados no texto são: Tony Xavier, Éverton dos Andes, Marcos Terra e Celma Terra.

O foco do trabalho é a relação afetiva da população da cidade tocantinense de Porto Nacional com o rio Tocantins, contextualizada no sentimento de perda diante da alteração da paisagem, com a formação do lago da Usina Hidrelétrica Luís Eduardo Magalhães. Os depoimentos de moradores ressaltam o prejuízo material para as populações ribeirinhas, cujo modo de vida estava associado à moradia na beira do rio e às atividades econômicas de subsistência (ibid., p. 5-8). A autora destaca a dimensão afetiva e estética desse sentimento de perda (ibid., p. 2-4).

Por Água Abaixo (Éverton dos Andes), canção citada por Messias (2008), remete a locais no leito do rio Tocantins que foram submersos após o fechamento das comportas da usina hidrelétrica. A inflexão saudosista do fonograma carrega uma multiplicidade de sentidos, incluindo protesto diante da perda dos bens naturais compartilhados e uma certa resignação pela impotência diante do progresso (Figura 9). 

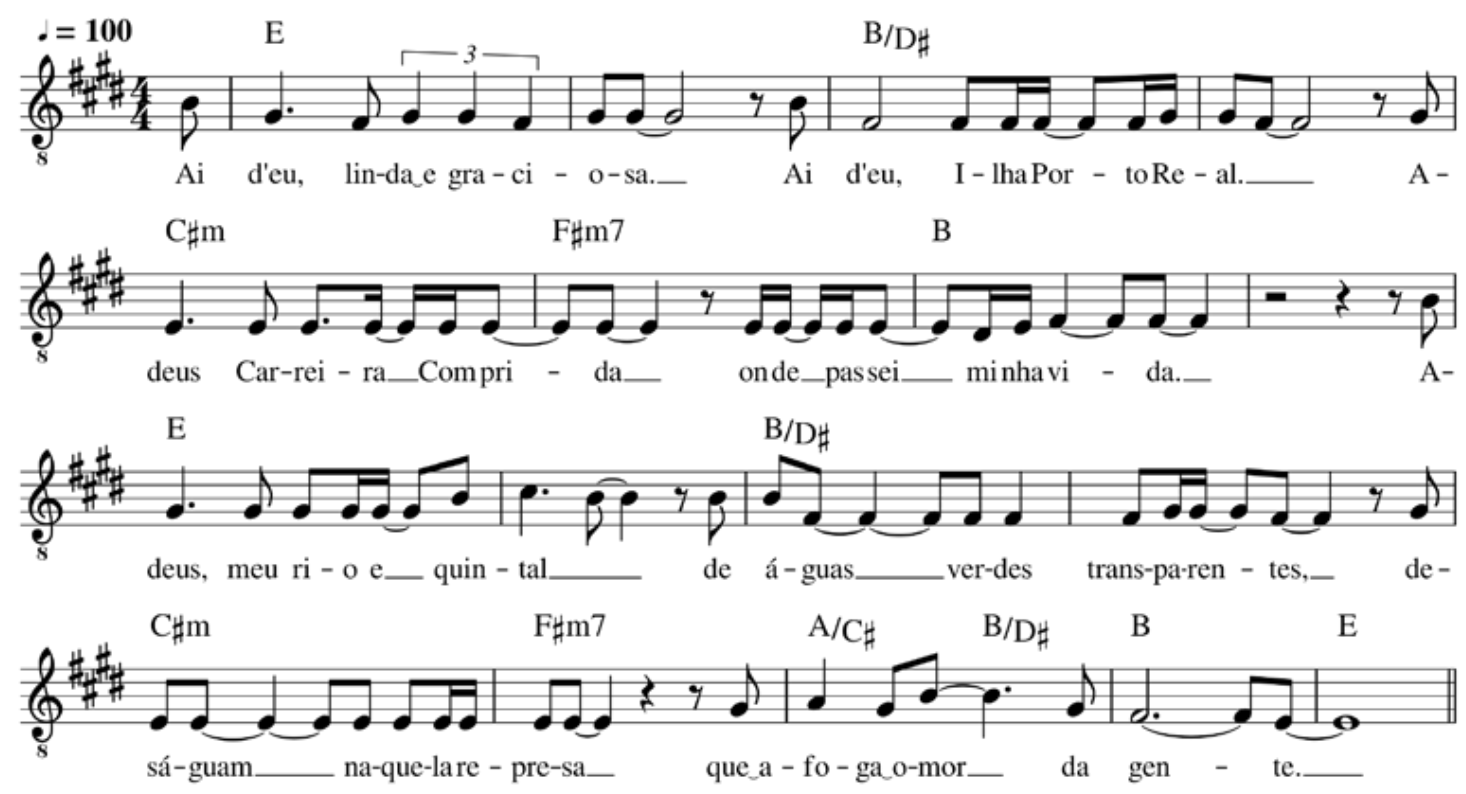

Figura 9: trecho de Por água abaixo (Éverton dos Andes)

$\mathrm{Na}$ canção, como nos depoimentos, fica evidente que naquele contexto de disputas e interesses diversos, enquanto uns perdem outros ganham. Ou seja, para uns, a transformação do rio em lago representa uma perda irreparável, posto que perderam um ecossistema que lhes garantia a sobrevivência. Para outros, essa transformação significa uma possibilidade a mais de lucro baseada nos recursos naturais da região (ibid., p. 10).

A oposição entre os que perdem e os que ganham com a modernização chama atenção para uma oposição mais geral no uso de referências locais pelos cancionistas. Em algumas canções, o "rio Tocantins" é tomado como um bem natural, representativo da construção identitária territorial regional. Em outras canções, "Tocantins" refere-se à própria delimitação político-administrativa a partir da qual decorrem ações de modernização como a hidrelétrica, aliando-se, portanto, ao território da política, cuja ênfase na invenção de identidade acaba por confundir-se com estratégias de legitimação de poder.

Em alguns casos, fica clara a intenção de associar "Tocantins" ao bem-estar social promovido pela autonomia político-administrativa e pela atuação dos governantes locais. Para os entrevistados, o ufanismo excessivo, evidente em algumas dessas canções, está associado ao interesse de inserção em benefícios aparentemente disponíveis para cancionistas e intérpretes com esse tipo de produção. "Acho lamentável que o sistema político através do qual as coisas acontecem deixe essa sensação de que é preciso apelar pra que o artista seja incluído. Porque, se apoiasse de verdade, cada qual no seu estilo, ficava um negócio bacana, mais consistente" (E1).

Verão no Tocantins, composta e interpretada por Relmivan Milhomem, foi gravada no início dos anos 2000 como trilha sonora para campanha promocional da temporada turística nas praias de rios, circuito característico da época de estiagem nas margens dos rios Tocantins e Araguaia. Adotando a ambientação sonora do reggae, que evoca imagens de genéricas de bem-estar e relaxamento, o fonograma oferece a lista dos principais destinos em linguagem de acento publicitário (Figura 10). 

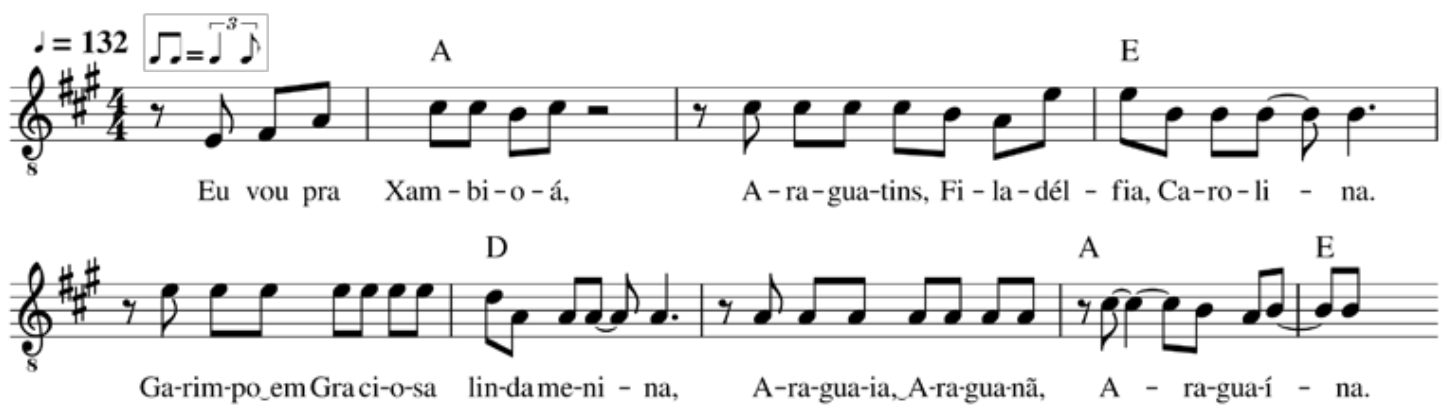

Figura 10: trecho de Verão no Tocantins (Relmivan Milhomem)

A canção Eu sou do Tocantins, pagode de Odilon Santos que também soa como jingle (Figura 11), é pontuada por citações das "belas cachoeiras, praias" e pelo convite: "venha conhecer o Tocantins". Em um trecho, o intérprete explica didaticamente que "o Tocantins é banhado por dois belíssimos rios: rio Araguaia, rio Tocantins".

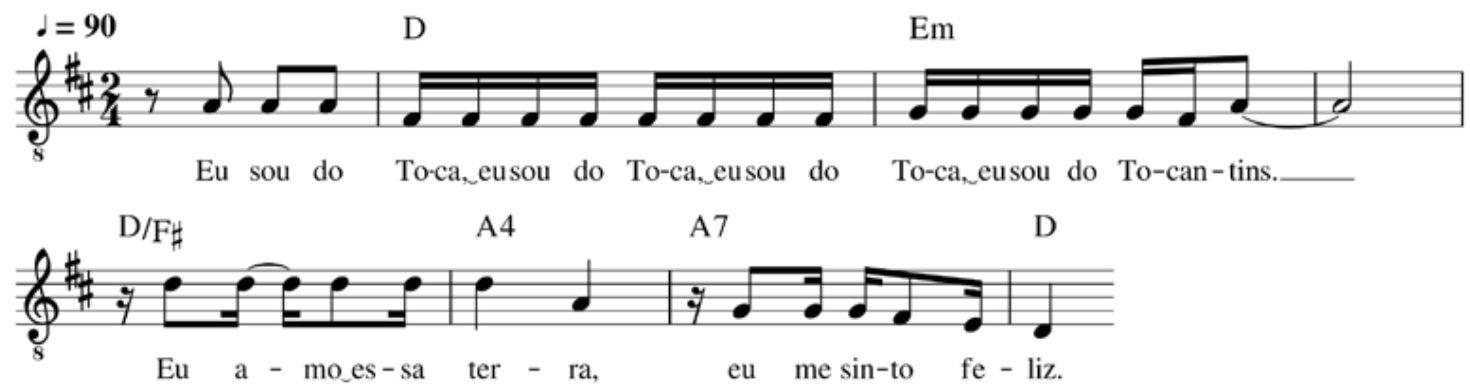

Figura 11: refrão de Eu sou do Tocantins (Odilon Santos)

Em exemplos como estes, a criação de canções alia-se à vertente do marketing turístico governamental. Sua posterior inserção em coletâneas difundidas como representativas da produção artística regional evidencia a transposição para o âmbito musical das tensões entre diversas visões sobre identidade no Tocantins. Em oposição à legitimação das canções jingle, os entrevistados posicionam-se a favor de uma abordagem mais sutil, calcada na possibilidade de captar uma espécie de essência da experiência regional: "O mais bonito é você sentir, ao invés de só referir" (E3). Ou de valer-se da história pessoal para compartilhar experiências estético culturais: "Eu canto aquilo que eu vivi, eu canto aquilo que eu absorvi durante toda a minha vida" (E1).

Canções aladas , composta e interpretada por Quésia Carvalho e vencedora do 30 Festival da Canção do Tocantins, constrói uma estratégia particularizada de simbolismo identitário, sem recorrer a referências óbvias ou expressões ufanistas (Quadro 1). 


\begin{tabular}{|c|c|c|}
\hline $\begin{array}{c}\text { CARACTERÍSTICA } \\
\text { RÍTMICA }\end{array}$ & LETRA & SEÇÃO \\
\hline Recitativo & $\begin{array}{l}\text { Na palma do buriti, um papagaio pousou } \\
\text { Ministrou-me o tagarela uma lição, amor } \\
\text { Quem não voa enxerga pouco } \\
\text { Se aninha em qualquer toco } \\
\text { Por isso convém voar } \\
\text { Quem cala a voz, perde a vez } \\
\text { Quem nunca sonhou, nada fez } \\
\text { A grande ventura do amor é se entregar }\end{array}$ & A \\
\hline Xote & $\begin{array}{l}\text { Mas quase sempre se ouve mais em meio } \\
\text { ao silêncio } \\
\text { Quando a natureza se faz ecoar } \\
\text { E a brisa fresca faz carícias em meu corpo } \\
\text { Domingo à tarde mergulhar faceira } \\
\text { co'as piabas } \\
\text { Servir-lhes banquete na palma da mão } \\
\text { Meu Deus, é tanta paz } \\
\text { Me esqueço até que o mundo é louco } \\
\text { Meu Deus, que bem me faz } \\
\text { Aíme lembro do meu povo } \\
\text { Derrama muito, muito mais } \\
\text { Pois já me parece tão pouco } \\
\text { Um temporal de paz para abrandar o } \\
\text { mundo todo }\end{array}$ & B \\
\hline Recitativo & $\begin{array}{l}\text { E o papagaio voou pra seguir seu destino } \\
\text { Pois o destino de ave é voar } \\
\text { Mas deixou-me esta canção, através da } \\
\text { qual voo } \\
\text { Porque as canções, as canções são aladas }\end{array}$ & $A^{\prime}$ \\
\hline Xote & - & Interlúdio \\
\hline Xote & Repetição idêntica & B \\
\hline
\end{tabular}

Quadro 1: letra e estrutura de Canções aladas (Quésia Carvalho)

Na seção $A^{\prime}$, culmina a narrativa de experiência vivida no contato com a natureza. $A$ linha melódica, em trajetória ascendente no verso "pois o destino de ave é voar", acompanha o voo da ave e o voo da experiência estética compartilhada pela cancionista com o ouvinte (Figura 12).

A canção atualiza o potencial da música regionalista de traduzir e ressignificar a experiência sertaneja (em seu sentido mais amplo) para a vida urbana moderna. 
E se temos razão em permanecer céticos a respeito das perspectivas romantizadas mais extremas que propõem a canção como "natural" ou "primeva", com sua bagagem etnocêntrica e paternalista, não podemos deixar de aceitar que há algo de encantamento - en-cantamento - nas palavras quando cantadas. $O$ espectro de possibilidades é rico e complexo [...]. Por meio de tais possibilidades, a voz que canta continua a aglutinar essas maravilhosas dimensões da cultura humana - verbal, musical, performática - no mesmo momento milagroso em que as palavras são cantadas (FINNEGAN, 2008, p. 40).

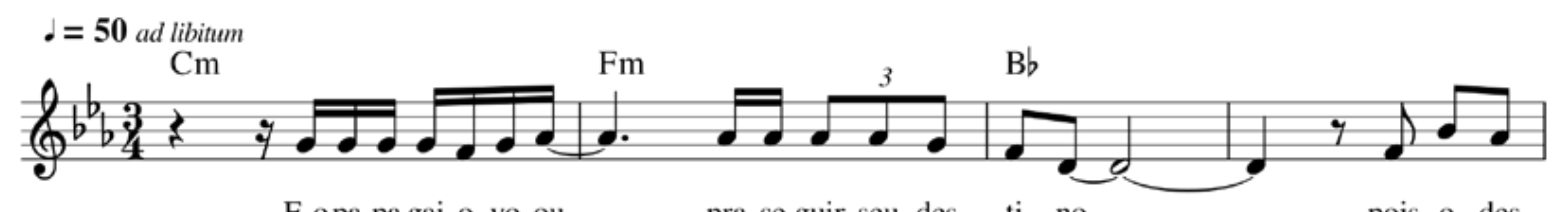

E_opa-pa-gai-o vo-ou__ pra se-guir seu des - ti - no, pois o des-

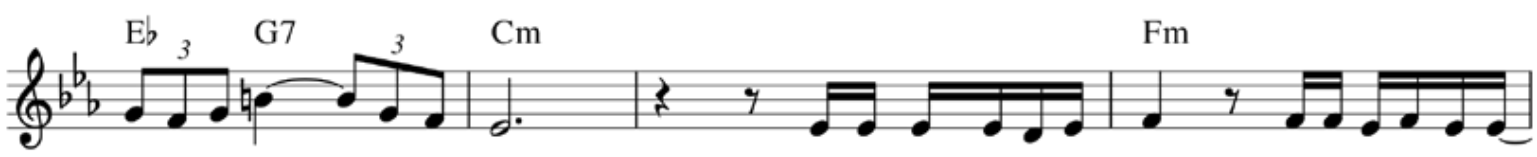

ti-no de a - ve_évo - ar.

Mas dei-xou-me_es-ta can - ção,

a-tra-vés da qual vo-

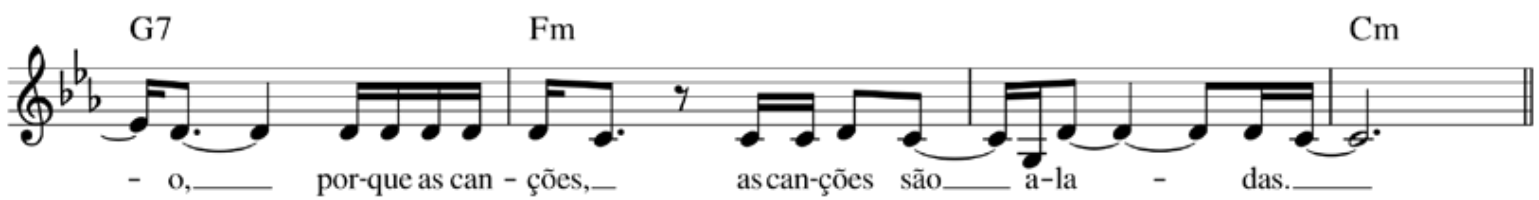

Figura 12: trecho de Canções Aladas (Quésia Carvalho): "E o papagaio voou..."

\section{Considerações finais: Tocantins, tensões, contradições, canções}

A cultura, fenômeno humano complexo, caracteriza-se pelo seu caráter diverso e dinâmico. As intensas trocas culturais, potencializadas pela sociedade tecnológica da atualidade, resultam em processos e ciclos de hibridação. Neste contexto, a ideia de identidade cultural é uma representação das diferenças como unidade. Essa unidade, entretanto, nunca se isenta dos jogos de poder, tensões e contradições que as diversas visões sobre tal unidade podem ocasionar.

Os discursos identitários inerentes à produção e recepção de canções do repertório regional do Tocantins remetem a discussões recorrentes em estudos sobre a música brasileira popular. Neste e em outros repertórios, as tensões e contradições dos discursos simbólicos (re)presentam identidades, autenticidades, regionalismos e tradições.

Ao longo das entrevistas, os ouvintes qualificados apontavam canções cuja musicalidade consideravam de cunho regionalista e outras que, mesmo adotando letras com referências locais, caracterizam-se mais por reproduzir gêneros consagrados na mídia nacional e internacional. O conceito de musicalidade regionalista implícito em suas falas admite referências tanto ligadas ao centro-oeste e centro-sul do país, quanto aquelas ligadas ao norte. A noção de uma herança rural compartilhada fundamenta a representação do contraponto que o regionalismo, no seu sentido mais amplo, constrói diante da modernidade e da homogeneização cultural. Os entrevistados se opõem à 
associação automática de referências locais nas letras com regionalismo na criação de canções. Admitem a diversidade de gêneros musicais como um dado marcante e representativo da cultura local, mas adotam seus próprios critérios para avaliar esteticamente os gestos criativos ditos regionalistas.

A criação de canções regionalistas representa um esforço criativo para construção simbólica de identidade, por meio de performances verbais e musicais. No repertório de canções regionais do Tocantins, há uma diversidade de estratégias criativas, alinhadas por sua vez a diferentes concepções sobre a identidade cultural do estado. As tensões e contradições resultantes podem ser sintetizadas em dois polos: de um lado, o território da política, com discurso identitário alinhado à legitimação do "Tocantins", unidade político-administrativa e suas estruturas de poder; de outro lado, a política do território, em que a ideia de identidade surge como expressão de experiências culturais compartilhadas. Classificar mecanicamente as canções como pertencentes a um ou outro polo seria um reducionismo. No entanto, é imprescindível ressaltá-los, uma vez que sintetizam as questões em jogo nos processos de produção e recepção da canção regionalista tocantinense, espaço imaginário de trocas entre cancionistas, intérpretes e ouvintes.

Este ensaio pode ser considerado uma abordagem preliminar das questões propostas, tendo mapeado temáticas e sugerido possíveis interpretações. Futuras pesquisas deverão abranger um número maior de cancionistas e canções, detalhar informações históricas disponíveis sobre a produção musical aqui delimitada e aprofundar o escopo teórico das análises, considerando seus aspectos sociológicos e musicológicos.

\section{REFERÊNCIAS}

ALENCAR, Maria Amélia Garcia de. A canção regionalista em tempos de modernidade. In: Congresso Latino-americano da Associação Internacional para o Estudo da Música Popular, V, Anais, Rio de Janeiro: Universidade Federal do Estado do Rio de Janeiro, 2004.

Cultura e Identidade nos Sertões do Brasil: representações na música popular, In: Congreso Latinoamericano de la Asociación Internacional para el Estudio de la Música Popular, III, Actas (IASPM), 2000.

ARAÚJO, Marcilene de Assis Alves. Linguagem e identidade cultural: uma abordagem sociolinguística. Sociodialeto, n. 3, 2011. Disponível em <http://www.sociodialeto.com. br/edicoes/8/09052011091540.pdf>, acesso em abr. 2012.

BONILLA, Marcus Facchin. Disseram que o samba voltou americanizado. DAPesquisa, n. 8. Florianópolis: Universidade do Estado de Santa Catarina, ago. 2010 - jul. 2011, p. 502-515. 
CANCLINI, Nestor García. Culturas Híbridas: estratégias para entrar e sair da modernidade. São Paulo: Editora da Universidade de São Paulo, 2006.

CAVALCANTE, Maria do Espírito Santo Rosa. Fronteiras de identidade regional no sertão do Brasil central. In: INTERNATIONAL CONGRESS OF THE LATIN AMERICAN STUDIES ASSOCIATION, XXIII, Proceedings... Washington, DC, 2001.

COELHO, Márcio Luiz Gusmão. O arranjo como elemento orgânico ligado à canção popular brasileira: uma proposta de análise semiótica. Tese (Doutorado em Semiótica). São Paulo: USP, 2007.

FINNEGAN, Ruth. O que vem primeiro: o texto, a música ou a performance? Tradução: Fernanda Teixeira de Medeiros. In: MATOS, Cláudia Neiva de; TRAVASSOS, Elizabeth; MEDEIROS, Fernanda Teixeira (Org.). Palavra cantada: ensaios sobre poesia, música e voz. Rio de Janeiro: 7Letras, 2008, p. 15-43.

FLORES, Kátia Maia. Caminhos que andam: o rio Tocantins e a navegação fluvial dos sertões. Goiânia: Ed. da UCG, 2009.

FUNDAÇÃO CULTURAL DO TOCANTINS. Selection de Chansons Regionales - Tocantins. CD. (Coletânea de vários autores e intérpretes). Palmas: FCT, 2005.

HALL, Stuart. A identidade cultural na pós-modernidade. 11a. ed. Rio de Janeiro: DP\&Editora, 2006.

MESSIAS, Noeci Carvalho. Águas mortas: reflexões sobre a memória de um patrimônio cultural perdido. In: ENCONTRO ESTADUAL DE HISTÓRIA - ANPUH-BA, IV. História: sujeitos, saberes e práticas. Vitória da Conquista: Universidade Estadual do Sudoeste da Bahia, 2008.

NAPOLITANO, Marcos; WASSERMAN, Maria Clara. Desde que o samba é samba: a questão das origens no debate historiográfico sobre a música popular brasileira. Revista Brasileira de História. São Paulo, v. 20, n. 39, 2000, p.167-189.

OLIVEIRA, Maria de Fátima. Rio Tocantins: lugar de memórias e identidades. Revista Mosaico, v. 1, n. 2, 2008, p. 163-168.

RODRIGUES, Jean Carlos. Experiência, identidade e a criação do Tocantins. Revista Formação Online, v. 1, n. 18, p. 24-38, jan./jun., 2011.

Política e religião na Nova Geografia Cultural: o caso da criação do estado do Tocantins. Revista de Estudos da Religião, Ano 9, junho, p. 51-72, 2009. 
SANTOS Júnior, Hemerson Ferreira dos. Identidade e distinção: a MPB em Goiás. Dissertação, Programa de Pós-Graduação em Sociologia, Faculdade de Ciências Sociais da Universidade Federal de Goiás, Goiânia, 2010.

TATIT, Luiz. O século da canção. Cotia: Ateliê Editorial, 2004.

TRAVASSOS, Elizabeth. Pontos de escuta da música popular no Brasil. In: ULHÔA, Martha; OCHOA, Ana Maria (org.). Música popular na América Latina: pontos de escuta. Porto Alegre: Editora da UFRGS, 2005, p. 94-111.

TROTTA, Felipe da Costa; LOPES, Ibrantina Guedes de Carvalho. Mídia, memória e música popular: cultura e identidade no forró "pé de serra" atual. In: CONGRESSO BRASILEIRO DE SOCIOLOGIA, XIV, Anais, Rio de Janeiro, 2009.

TROTTA, Felipe; CASTRO, João Paulo M. A construção da ideia de tradição no samba. Cadernos do Colóquio, p. 62-74, dezembro de 2001.

ULHÔA, Martha Tubinambá de. Pertinência e música popular: em busca de categorias para análise da música brasileira popular. Cadernos do Colóquio, dez. 2001, p. 50-61.

Nova história, velhos sons: notas para ouvir e pensar a música brasileira popular. Debates, v. 1, n. 1, 1997, p. 80-101.

ZAN, José Roberto. Música popular brasileira, indústria cultural e identidade. EccoS Revista Científica, São Paulo, UNINOVE, v. 3, n. 1, 2001, p. 105-122. 